\title{
Structure and development of fruits and seeds of weed species of Euphorbiaceae
}

Karina Bertechine Gagliardi ${ }^{1,3}$, Aline Rosado ${ }^{1}$, Luiz Antonio de Souza ${ }^{1}$, Ismar Sebastião Moscheta ${ }^{1}$ and Adriana Lenita Meyer Albiero ${ }^{2}$

Recebido em 26/07/2011. Aceito em 31/10/2011

\begin{abstract}
RESUMO
(Estrutura e desenvolvimento de frutos e sementes de espécies invasoras de Euphorbiaceae). Euphorbiaceae s.l. apresenta vários tipos morfológicos de frutos, sendo o mais comum o esquizocarpo. Os frutos das espécies invasoras Euphorbia graminea Jacq., Euphorbia heterophylla L., Euphorbia hirta L. (= Chamaesyce hirta (L.) Millsp.) and Euphorbia prostrata Aiton (= Chamaesyce prostrata (Aiton) Small) são objetos do presente estudo. As inflorescências e frutos em desenvolvimento foram coletados no campus da Universidade Estadual de Maringá (UEM), Brasil, fixados em FAA 50 e glutaraldeído, desidratados e secionados em micrótomo de rotação, de acordo com as técnicas usuais em anatomia. As espécies apresentam muitas semelhanças anatômicas, embora haja algumas diferenças relacionadas à epiderme externa do ovário, que é glabra em E. graminea e pilosa nas outras espécies. O fruto maduro apresenta exocarpo papiloso e desprovido de tricomas, com exceção de E. hirta. O óvulo é anátropo, bitegumentado e crassinucelado, e as sementes são exotégmicas com embriões retos.
\end{abstract}

Palavras-chave: Euphorbia, ontogenia, pericarpo, esquizocarpo, tegumento seminal

\begin{abstract}
(Structure and development of fruits and seeds of weed species of Euphorbiaceae). Euphorbiaceae s.l. presents several morphological types of fruits, of which the schizocarp is the most common. The fruits of weed species of Euphorbia graminea Jacq., Euphorbia heterophylla L., Euphorbia hirta L. (= Chamaesyce hirta (L.) Millsp.) and Euphorbia prostrata Aiton (= Chamaesyce prostrata (Aiton) Small) are objects of this study. Inflorescences and fruits in development were collected on the campus of the State University of Maringa (UEM), Brazil, fixed in FAA 50 and glutaraldehyde, dehydrated and sectioned with a rotary microtome according to standard morphology and anatomy techniques. The species present several anatomical similarities, though there are some differences related to the outer epidermis of the ovaries, which is glabrous in E. graminea and hairy in the other species. The ripe fruits present a papilose exocarp and lack trichomes, except for E. hirta. The ovules are anatropous, bitegmic and crassinucellate; the seeds are exotegmic and the embryos are straight.
\end{abstract}

Key words: Euphorbia, ontogeny, pericarp, schizocarp, seedcoat

\section{Introduction}

Euphorbiaceae s.l. presents several morphological types of fruits, such as a bacca, coccarium and polospermatium (Spjut 1994) or schizocarp, capsule, drupe or a berry (Barroso et al. 1999). Judd et al. (2002) consider that Euphorbiaceae s.s. usually present a schizocarp with elastically dehiscent segments from a persistent central column. On the other hand, from a structural aspect, the fruit (pericarp) of studied Euphorbiaceae species are similar (Toledo 1963; Berg 1975; Oliveira \& Oliveira 2009; Silva \& Souza 2009), in which the formation of sclerenchymatous tissue may be considered one of the most important events in the ontogeny of the fruit (Silva \& Souza 2009).

The ovules and seeds of Euphorbiaceae were widely studied by Landes (1946), Singh (1954), Toledo (1963), Singh \& Chopra (1970), Berg (1975), Corner (1976), Paoli et al. (1995), Tokuoka \& Tobe $(1998 ; 2002 ; 2003)$, Añes et al. (2005) and Silva \& Souza (2009). The studies of Tokuoka \& Tobe $(1998 ; 2002 ; 2003)$ have systematic implications and they showed that the five following characters are likely to be useful for comparison between and within subfamilies:

\footnotetext{
Universidade Estadual de Maringá, Departamento de Biologia, Maringá, PR, Brasil

2 Universidade Estadual de Maringá, Departamento de Farmacologia e Terapêutica, Maringá, PR, Brasil

3 Author for correspondence: karina_bertechine@msn.com
} 
a) whether the inner integument is thick or thin; b) the presence or absence of vascular bundles in the inner integument; c) whether ovules or seeds are pachychalazal or not; $d$ ) whether seeds are arillate or not; and e) whether the exotegmen is fibrous or not.

The fruits of weed species of the Euphorbia L. are objects of the present study. The selected species were Euphorbia graminea Jacq., Euphorbia heterophylla L., Euphorbia hirta L. (=Chamaesyce hirta (L.) Millsp.) and Euphorbia prostrata Aiton (= Chamaesyce prostrata (Aiton) Small). The genus belongs to the large tribe Euphorbieae (Euphorbioideae), which is considered monophyletic on the basis of the inflorescence (cyathium) (Judd et al. 2002). Bruyns et al. (2006) argues that each cyathium consists of a cupular involucre (made up of four or five fused bracts), and male flowers inside this involucre surrounding a single female flower. The tribe Euphorbieae was divided into three subtribes, of which Euphorbiinae is the largest and nearly cosmopolitan. In this subtribe the involucre is made up of five bracts, the male flowers lack a perianth and the female flowers are also mostly devoid of a perianth (Webster 1975). According to Webster (1994) the genus Euphorbia belongs to this subtribe. Numerous Euphorbieae specialists retain Chamaesyce Raf. as a subgenus of Euphorbia (Steimann \& Porter 2002). With about 300 species, Chamaesyce is the largest segregate genus of Euphorbia and is widespread, although most species are confined to the New World (Steimann \& Porter 2002). The present research deals with the structure and development of fruits (pericarp) and seeds of selected weed species, with emphasis on: a) the definition of the fruit type of the studied species; b) the discussion about the origin and differentiation of the sclerenchymatous tissue which occurs in the species; $c$ ) the evaluation of whether the ovules and seeds of the species present the basic characters of Euphorbioideae and Euphorbieae that were formulated by Tokuoka \& Tobe (2002); and d) an analysis to see if there are significant structural differences of the fruits and seeds among the species of Euphorbia and Chamaesyce.

\section{Material and methods}

Developing inflorescences and fruits of Euphorbia species were collected on the campus of the State University of Maringa (UEM), Brazil (state of Paraná), in the following locations: Euphorbia graminea, 506m altitude, $23^{\circ} 24^{\prime} 13.3^{\prime \prime}$ latitude, $51^{\circ} 56^{\prime} 21.17^{\prime \prime}$ longitude; Euphorbia heterophylla, 522m altitude, $23^{\circ} 24^{\prime} 14.4^{\prime \prime}$ latitude, $51^{\circ} 56^{\prime} 20.3^{\prime \prime}$ longitude; Euphorbia hirta, $519 \mathrm{~m}$ altitude, $23^{\circ} 24^{\prime} 13.9^{\prime \prime}$ latitude, $51^{\circ} 56^{\prime} 20.7^{\prime \prime}$ longitude; Euphorbia prostrata, $519 \mathrm{~m}$ altitude, $23^{\circ} 24^{\prime} 13.9^{\prime \prime}$ latitude, $51^{\circ} 56^{\prime} 20.7^{\prime \prime}$ longitude. Voucher material was deposited in the UEM Herbarium, with the following collection numbers: $E$. graminea - 19462HUEM, E. heterophylla - 14505HUEM, E. hirta - 19463HUEM, and E. prostrata - 19464 HUEM.

The collected material was fixed in FAA 50 (formalin, acetic acid, ethanol) and glutaraldehyde ( $1 \%$ in $0.1 \mathrm{M}$ phos- phate buffer, $\mathrm{pH} 7.2$, maintained at $4^{\circ} \mathrm{C}$ )., transferred into $70 \%$ alcohol, following the protocol of Johansen (1940), dehydrated through an alcohol series, embedded in hydroxymethacrylate (Gerrits 1991), sectioned with a rotary microtome (cross and longitudinal sections), and stained with $0,05 \%$ toluidine blue in a phosphate buffer at $\mathrm{pH} 4.7$ (O'Brien et al. 1964). Freehand, semi-permanent slides with cross and longitudinal sections were made and were stained using safranin and astra blue.

Specific microchemical tests were carried out for lignin phloroglucinol with hydrochloric acid and for lipid substances with Sudan III (Johansen 1940).

Photomicrographs were prepared using a Leica EZ4D stereoscope camera and an Olympus BX50 optical microscope, which was fitted with a digital Canon Power Shot A95 camera, and subsequently processed using the software Leica Application Suite version 1.8.1 and Zoom Browser EX 4.6, respectively.

Micromorphological analyses (Bozzola \& Russel 1992) were done with material fixed in glutaraldehyde. After washing in a $0.1 \mathrm{M}$ sodium cacodylate buffer, the samples were dehydrated in a graded acetone series, critical point dried with $\mathrm{CO}_{2}$, mounted on aluminum stubs, coated with gold, and subsequently examined using Scanning Electronic Microscopy (SEM) (Shimadzu SS-550 Superscan) to obtain digital images.

The terminology employed in the analysis of the fruits and seeds was based on Martin (1946), Corner (1976), Roth (1977), Spjut (1994) and Barroso et al. (1999).

\section{Results}

\section{Ovary structure and fruit development}

The 3-carpellate ovary (Fig. 1-2) is connate, 3-lobed, has one ovule in each locule and axile placentation. The outer epidermis is uniseriate and papillose, and is glabrous in $E$. graminea (Fig. 1) and hairy in the other species (Fig. 2, 3) (unicellular nonglandular trichomes in E. heterophylla and long multicellular nonglandular trichomes in E. hirta and E. prostrata). The mesophyll (Fig. 3) is a little narrower in $E$. hirta and E. prostrata than in the other species and presents three different regions: a) an outer parenchymatous region that consists of thin-walled and isodiametric cells; b) a middle region with two to four layers of slightly tangentially elongated cells; and c) an inner uniseriate tissue with short palisade-like cells. The inner epidermis consists of two or three cellular layers with pluricellular trichomes (Fig. 4). The pluriseriate middle mesophyll and the inner epidermis result from the meristems, which develop on the mesophyll and adaxial epidermis of the bud ovary wall.

The pericarp (Fig. 5) derived from the ovary wall is composed of a uniseriate exocarp, mesocarp with three regions of tissues and an endocarp with two or three layers of cells. An enlargement of the cells contributes in the growth 

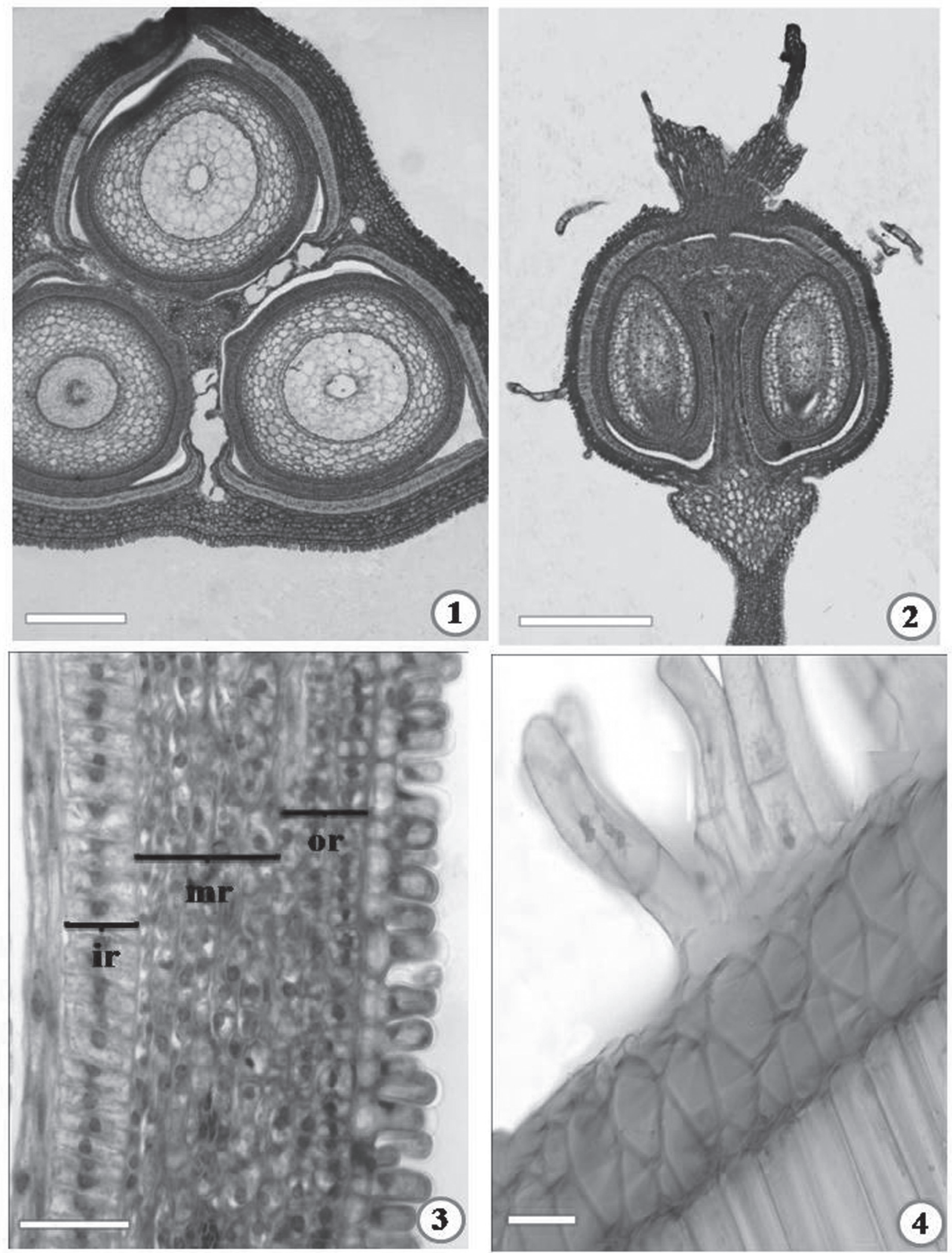

Figure 1. Ovary of Euphorbia graminea Jacq in cross section. Scale $=250 \mu \mathrm{m}$. Figure 2. Ovary of Euphorbia hirta L. in longitudinal section. Scale $=250 \mu \mathrm{m}$. Figure 3. Ovary mesophyll of Euphorbia heterophylla L. showing outer region (or), middle region (mr) and inner region (ir). Scale $=50 \mu \mathrm{m}$. Figure 4 . Detail of inner epidermis of Euphorbia heterophylla L. Scale $=250 \mu \mathrm{m}$. 
of the fruit wall. The middle mesocarp and endocarp cells undergo tangential elongation (Fig. 5). The cells of the inner mesocarp become conspicuous by their radial elongation (Fig. 5). The walls of middle mesocarp, inner mesocarp and endocarp cells gradually become thicker. The septum originates from cohesion of the carpel walls. Most of the septum has a structure similar to the remaining part of the carpel.

In ripe fruits (Fig. 6, 7, 8, 9), the exocarp cells resemble the ones in the single-layered outer epidermis of the ovary. The exocarp is papillose and lacks trichomes, except for $E$. hirta that has pluricellular, nonglandular trichomes. The outer mesocarp is parenchymatous, although much larger in E. heterophylla. In this layer there are collateral vascular bundles. The middle mesocarp is composed of lignified or non-lignified fibers. The inner mesocarp is formed by lignified, thick-walled macrosclereids that are more or less perpendicularly arranged to the middle mesocarp. The biseriate or triseriate endocarp is composed of non-lignified fiber-like cells and an epidermis with trichomes.

The fruit presents two dehiscent regions: a dorsal region and another region along the carpel sutures. In the dorsal dehiscence of each carpel the exocarp and outer mesocarp undergo a few structural alterations, but the middle mesocarp fibers, and inner mesocarp macrosclereids, are substituted gradually by isodiametric cells; the endocarp cells become thick-walled (Fig. 7). In the ventral suture there is dehiscence abscission tissue among the carpel walls; this consists of spongy parenchyma with cells that develops arms. The carpophore is separate from the septum for the abscission tissue (Fig. 9).

\section{Ovule structure and seed development}

The ovule is anatropous, bitegmic, crassinucellate with the micropyle formed by both inner and outer integuments (Fig. 10). The exostome and endostome are both in line in $E$. hirta and E. prostrata and the micropylar canal has a kind of zigzag outline in E. graminea (Fig. 10) and E. heterophylla. Through division of the cells in the micropylar end of the nucellus, a cell proliferation is developed and it extends beyond the micropyle. The outer integument consists of three or four layers of cells (Fig. 12). The inner integument of E. graminea and E. heterophylla (7-10 cell-layers) is much thicker than in E. hirta and E. prostrata.

In the developing seed, the number of cell-layers of the inner integument multiplies slightly in E. graminea and $E$. heterophylla, whereas the number of cell-layers in the testa remains the same (Fig. 12). The cells of the testa maintain thin walls. Especially, the cells of the outer tegmen epidermis become conspicuous because of their radial elongation and deep staining capacity. The aril (Fig. 11) is formed in the exostome of the young seeds of the Euphorbia species in which cells of the mesophyll of the outer integuments undergo division and radial elongation. The endosperm is nuclear.

At maturity the seed coat consists of both testa and tegmen, but the former is unspecialized (Fig. 13). The ex- otesta of E. hirta, E. prostrata and E. heterophylla consists of shortly projecting cells which extend towards the endocarp (Fig. 6, 14, 15). The mesotesta is crushed and the endotesta cells become slightly thick-walled. The exotegmen cells of E. graminea and E. heterophylla undergo elongation and a secondary thickening of the cell wall becomes lignified thick-walled macrosclereids arranged in palisade layer in the mature seed; E. hirta and E. prostrata have an exotegmen with a short palisade layer (Fig. 13). The mesotegmen is parenchymatous and the endotegmen consists of thin-walled and irregular cells (Fig. 13); both may be crushed in the ripe seed. The aril was not observed in the ripe seeds. The embryo is relatively large and straight (Fig.16, 17).

\section{Discussion}

As a dorsiventral structure, the carpel can develop a so-called ventral meristem on its inner surface, either in subepidermal layers or in the inner epidermis itself (or both strata); in very peculiar cases, a dorsal meristem can develop (Roth 1977). Leguminosae and Rutaceae fruits have a ventral or adaxial meristem (Souza 1984; 1993; Souza et al. 2003) and Bignoniaceae fruits present a middle meristem (Souza et al. 2005). Fruits of Euphorbia species develop two meristems, one in the middle region of the mesophyll and the other in the inner epidermis of the floral bud ovary. Euphorbia fruits are similar to those of Dalechampia stipulaceae Müll. Arg. (Silva \& Souza 2009). Manihot fruits also present two meristems (subadaxial and adaxial) that originate in the inner mesocarp and endocarp, respectively (Oliveira \& Oliveira 2009).

The fruit wall may be arbitrarily divided into layers that are referred to as the exocarp (outer layer), mesocarp (middle layer) and endocarp (inner layer) (Spjut 1994), or may involve ontogenetic study of the pericarp (Roth 1977; Souza 2006). Based on the ontogeny study, the Euphorbia fruits were found to be relatively uniform presenting an epidermal exocarp, parenchymatous and sclerenchymatous mesocarp, and endocarp which consists of an epidermis and fibrous cells. Dalechampia stipulaceae fruits (Silva \& Souza 2009) match Euphorbia fruits in having the epidermal exocarp and mesocarp with parenchyma and sclerenchyma (fibers and macrosclereids), although they differ by the endocarp, which only has fibers. On the other hand, Manihot fruits have no macrosclereids in the mesocarp, but they present gelatinous fiber-sclereids in the middle mesocarp, stone cells in the inner mesocarp and a collenchymatous endocarp (Oliveira \& Oliveira 2009).

Fibers and macrosclereids of Euphorbia fruits are arranged in the mesocarp so that the cells of one layer cross the cells of another layer. It is probable that this crossed arrangement of cells is related to the movement of water lost during the dehiscence mechanism called xerochasy (Roth 1977). In agreement with this author, during water loss stress is exercised on the pericarp, and the fruit consequently opens. 

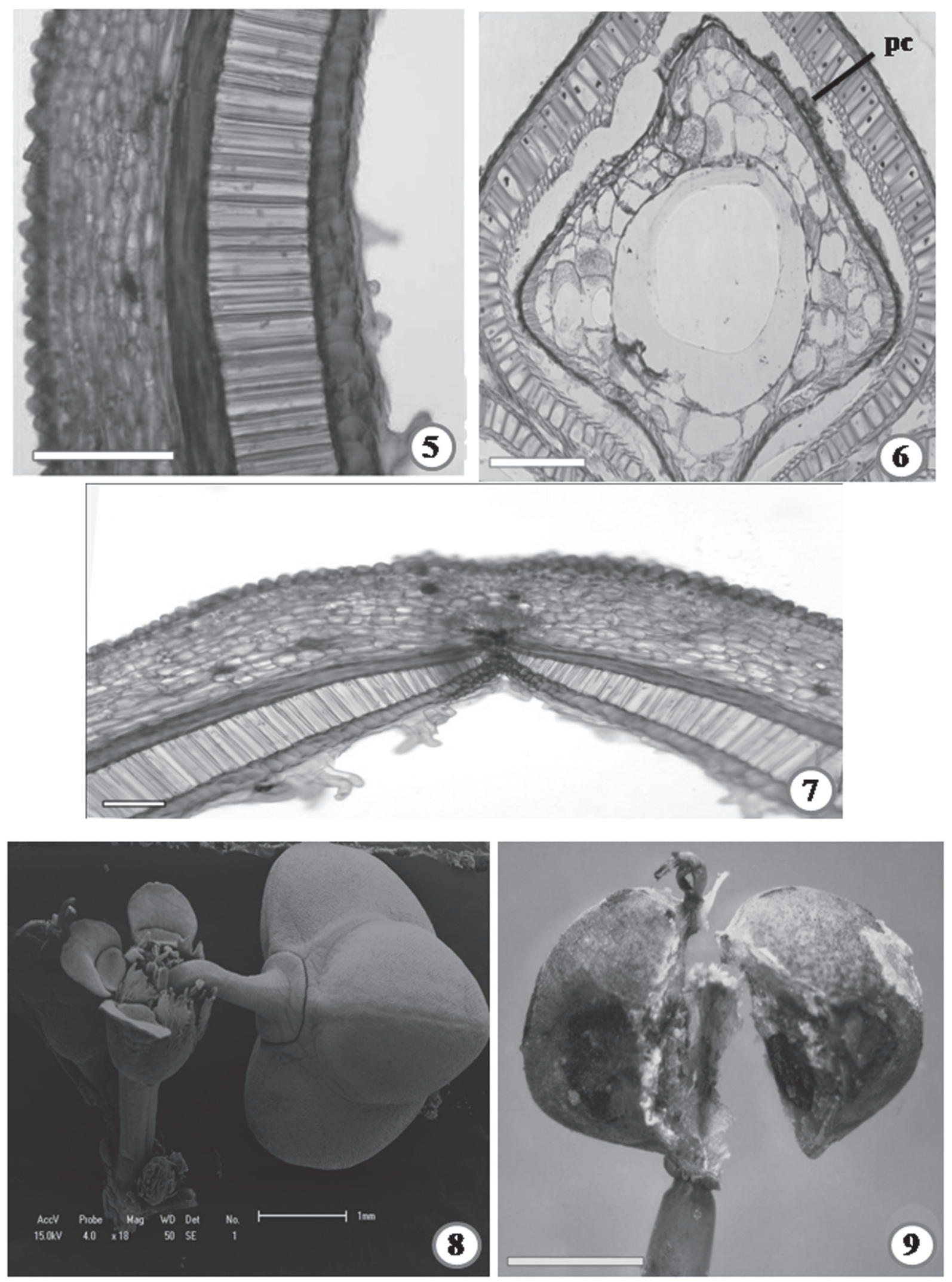

Figure 5. Immature pericarp of Euphorbia heterophylla L. Scale $=400 \mu \mathrm{m}$. Figure 6. Ripe pericarp and seed of Euphorbia prostrata Aiton. Note the projecting cells $(\mathrm{pc})$. Scale $=250 \mu \mathrm{m}$. Figure 7. Dorsal region of the pericarp of Euphorbia heterophylla L. Scale $=500 \mu \mathrm{m}$ Figure 8. Scanning electronic microscopy $(\mathrm{SEM}) \mathrm{mi}-$ crography of the inflorescence of Euphorbia graminea Jacq with fruit. Scale $=1 \mathrm{~mm}$. Figure 9. Schizocarp with mericarps separating from each other of Euphorbia heterophylla L. Scale $=3 \mathrm{~mm}$. 

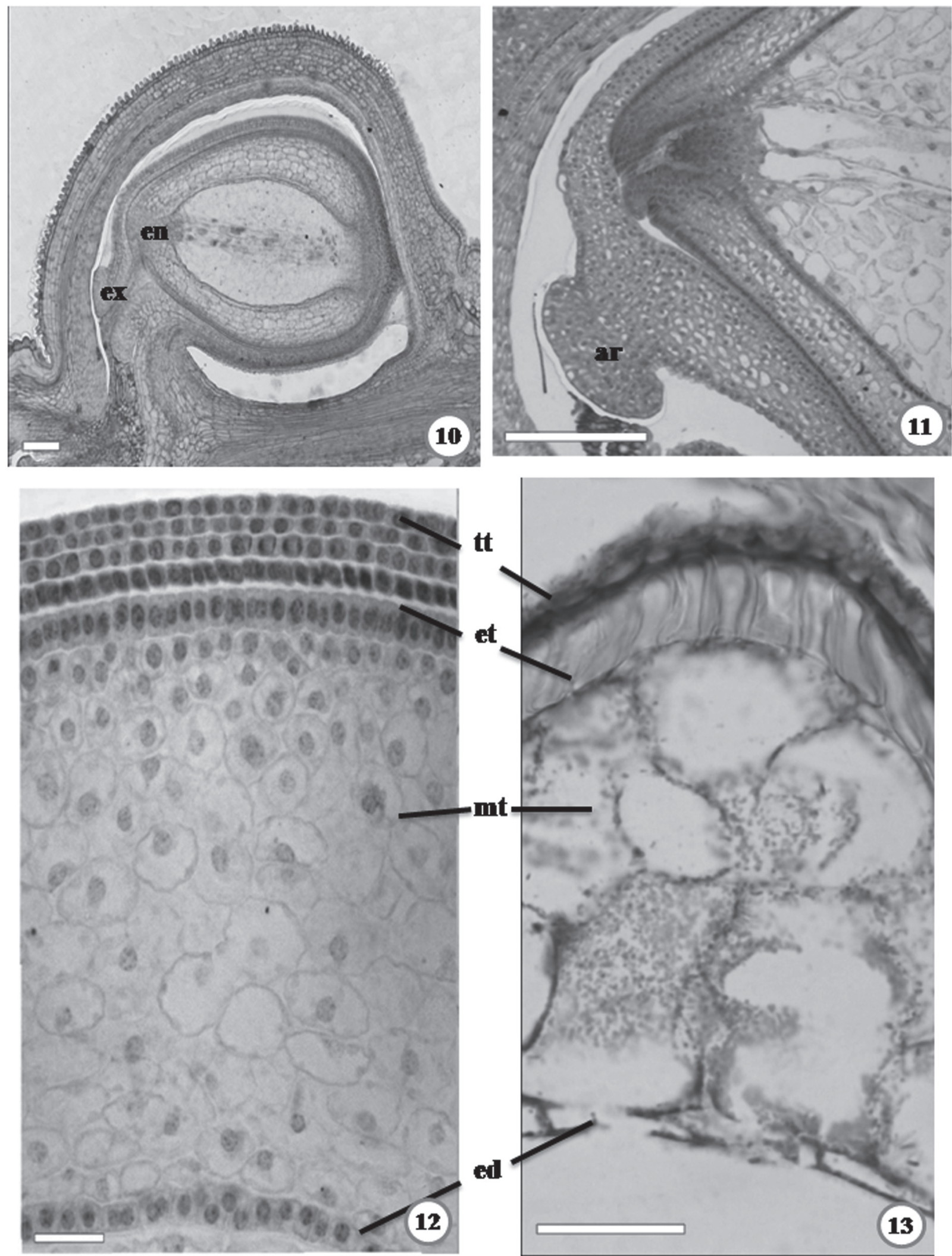

Figure 10. Anatropous and crassinucellate ovule of Euphorbia graminea Jacq. Note the exostome (ex) and endostome (en). Scale $=250 \mu \mathrm{m}$. Figure 11. Detail of the micropylar region of the young seed of Euphorbia heterophylla L. with aril (ar). Scale $=100 \mu \mathrm{m}$. Figure 12, 13. Young seed of Euphorbia heterophylla L. and detail of seed-coat of Euphorbia prostrata Aiton. Note the testa (tt), exotegmen (et), mesotegmen (mt) and endotegmen (ed). Scales $=100 \mu \mathrm{m}$ and $250 \mu \mathrm{m}$. 

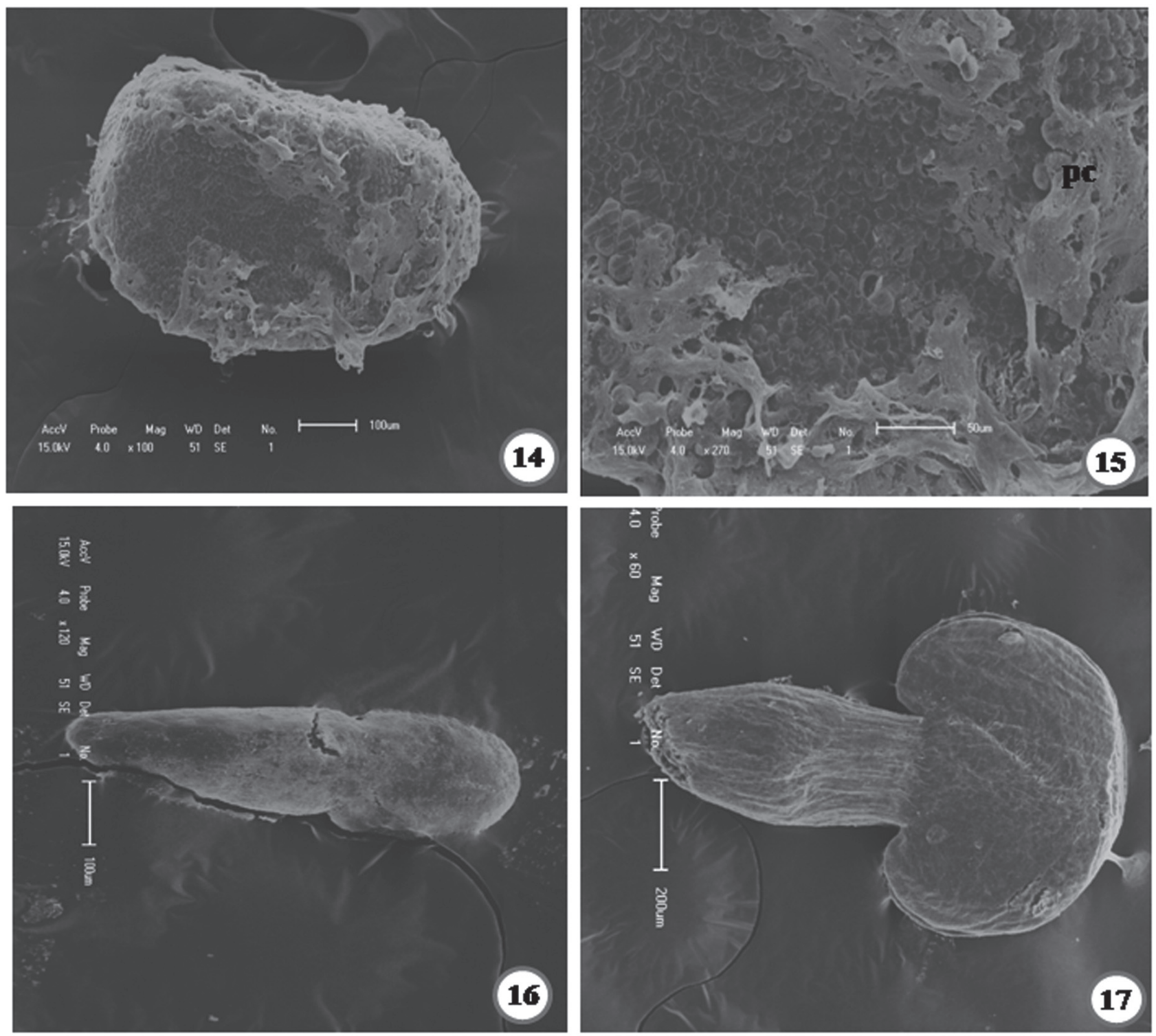

Figure 14, 15. SEM micrographies of the ripe seed of Euphorbia hirta L. and its seed coat. Note the testa (white) with projecting cells $(\mathrm{pc})$. Scale $=100 \mu \mathrm{m}$ and 50 $\mu \mathrm{m}$. Figure 16, 17. SEM micrographies of the embryos of Euphorbia hirta L. and Euphorbia graminea Jacq. Scales $=100 \mu \mathrm{m}$ and $200 \mu \mathrm{m}$.

In the dehiscence mechanism of the Euphorbia fruits the presence of the separation tissue placed among the carpels is essential, occurring in the median plane of the carpel and among the carpels and carpophore.

Based on the dehiscence type and persistent carpophore (Barroso et al. 1999), the Euphorbia fruits should be classified as schizocarps. According to Spjut (1994), these schizocarpic fruits can be considered as the coccarium type, a fruit derived from a schizocarpous gynoecium characterized by fruitlets opening along their ventral sutures, and sometimes the dorsal sutures, as a result of their separation from one another or from the central axis.

The ovule and seed structure of the Euphorbia species was found to be relatively uniform. However, comparisons of the species show variations in the thickness of the inner integument, micropyle morphology (exostome and endostome) and size of the exotegmen cells. Both E. hirta $(=C$. hirta $)$ and E. prostrata $(=C$. prostrata $)$ are distinct from the other Euphorbia species in having a thin inner integument, exostome and endostome in line and short palisade cells. Other Euphorbiaceae species, such as Euphorbia esula L. (Selbo \& Carmichael 1999), present the same characteristic as E. heterophylla and E. graminea, such as a micropyle with an exostome and endostome in a zig-zag.

The seeds of the studied species have the basic structural characters of Euphorbiaceae and Euphorbia (Corner 1976). According to this author, the seeds are exotegmic in which the mechanical layer consists of an outer epidermis with palisade and more or less prismatic cells. Based on the embryo classification formulated by Martin (1946), all Euphorbia embryos have been placed within the major 
group termed axile division; the type is foliate subdivision, spatulate subtype.

Regardless of their few differences, the seeds of Euphorbia species present the general structure of the ovules and seeds reported by Tokuoka \& Tobe (2002) for the subfamily Euphorbioideae: bitegmic ovules, inner integuments without vascular bundles, outer integument without postchalazal branching, ovules with an aril, and exotegmic seeds with radially elongated cells. Based on the differences in the thickness of the inner integument in the tribe Euphorbieae and Euphorbia species, Tokuoka \& Tobe (2002) suggested a more extensive study to confirm if this character is related to evolutionary relationships within the genus.

Although the sample of the species is not broad enough to make a definitive conclusion, this fruit/seed study supports the proposition of the Euphorbieae specialists, which is to retain Chamaesyce as a subgenus of Euphorbia.

\section{Acknowledgments}

We thank CNPq ("Conselho Nacional de Desenvolvimento Científico e Tecnológico, Brasil”) for the support granted to this work and Dr. Inês Cordeiro (Institute of Botany, Brazil) for identifying the species.

\section{References}

Añes, L.M.M.; Coelho, M.F.B.; Albuquerque, M.C.F. \& Dombroski, J.L.D. 2005. Caracterização morfológica dos frutos, das sementes e do desenvolvimento das plântulas de Jatropha elliptica Müll. Arg. (Euphorbiaceae). Revista Brasileira de Botânica 28: 563-568.

Barroso, G.M.; Morim, M.P.; Peixoto, A.L. \& Ichaso, C.L.F. 1999. Frutos e sementes (morfologia aplicada à sistemática de dicotiledôneas). Viçosa, Editora Universidade Federal de Viçosa.

Berg, R.Y. 1975. Fruit, seed, and myrmecochorous dispersal in Micrantheum (Euphorbiaceae). Norweg Journal of Botany 22: 173-194.

Bozzola, J.J. \& Russell, L.D. 1992. Electron microscopy. Boston, Jones and Bartlett Publishers.

Bruyns, P.V.; Ruvimbo, J. \& Mapaya, T.H.A. 2006. New subgeneric classification for Euphorbia (Euphorbiaceae) in Southern Africa based on ITS and psbA-trnH sequence data. Taxon 55(2): 397-420.

Corner, E.J.H. 1976. The seeds of dicotyledons. Cambridge, Cambridge University Press.

Gerrits, P.O. 1991. The application of glycol methacrylate in histotechnology; some fundamental principles. Gröningen, Departament of Anatomy and Embriology State University.

Johansen, D.A. 1940. Plant microtechnique. New York, McGraw-Hill.

Judd, W.S.; Campbell, C.S.; Kellogg, E.A.; Stevens, P.F. \& Donoghue, M.J. 2002. Plant systematics - a phylogenetic approach. 2 ed. Sunderland, Sinauer Associates.

Landes, M. 1946. Seed development in Acalypha rhomboidea and some other Euphorbiaceae. American Journal of Botany 33(6): 562-568.
Martin, A.C. 1946. The comparative internal morphology of seeds. The American Midland Naturalist 36(3): 513-660.

O’Brien, T.P.; Feder, N. \& Mccully, M.E. 1964. Polychromatic staining of plant cell walls by toluidine blue O. Protoplasma 59: 368-373.

Oliveira, J.H.G. \& Oliveira, D.M.T. 2009. Morfoanatomia e ontogênese do pericarpo de Manihot caerulescens Pohl e M. tripartita Müll. Arg. (Euphorbiaceae). Revista Brasileira de Botânica 32(1): 117-129.

Paoli, A.A.S.; Freitas, L. \& Barbosa, J.M. 1995. Caracterização morfológica dos frutos, sementes e plântulas de Croton floribundus Spreng. e de Croton urucurana Baill. (Euphorbiaceae). Revista Brasileira de Sementes 17: 57-68.

Roth, I. 1977. Fruits of angiosperms. Pp. 175-361. In: Linsbauer, K.; Tischler, F.G.\& Pascher, A. (Ed.). Encyclopedia of plant anatomy. Berlin, Gebrüder Borntraeger.

Selbo, S.M. \& Carmichael, J.S. 1999. Ovule, embryo sac, embryo, and endosperm development in leafy spurge (Euphorbia esula). Canadian Journal of Botany 77: 599-610.

Silva, A.C. \& Souza, L.A. 2009. Morphology and anatomy of the developing fruit and seed of Dalechampia stipulacea Müll. Arg. (Euphorbiaceae). Acta Scientiarum, Biological Sciences 31(4): 425-432.

Singh, R.P. 1954. Structure and development of seeds in Euphorbiaceae: Ricinus communis L. Phytomorphology 4: 118-123.

Singh, R.P. \& Chopra, S. 1970. Structure and development of seeds in Croton bonplandianum. Phytomorphology 20: 83-87.

Souza, L.A. 1984. Anatomia do desenvolvimento do pericarpo de Lonchocarpus muehlbergianus Hassler (Leguminosae - Faboideae). Revista Unimar 6(1): 5-19.

Souza, L.A. 1993. Morfo-anatomia do desenvolvimento do fruto de Acacia paniculata Willd. (Leguminosae). Arquivos de Biologia e Tecnologia 36(4): 851-871.

Souza, L.A. 2006. Fruto. Pp. 9-123. In: Souza, L.A. (Org.). Anatomia do fruto e da semente. Ponta Grossa, Editora UEPG.

Souza, L.A.; Iwazaki, M.C. \& Moscheta, I.S. 2005. Morphology of the pericarp and seed of Tabebuia chrysotricha (Mart. ex DC.) Standl. (Bignoniaceae). Brazilian Archives of Biology and Technology 48(3): 407-418.

Souza, L.A.; Mourão, K.S.M.; Moscheta, I.S. \& Rosa, S.M. 2003. Morfologia e anatomia da flor de Pilocarpus pennatifolius Lem. (Rutaceae). Revista Brasileira de Botânica 26(2): 175-184.

Spjut, R.W. 1994. A systematic treatment of fruit types. Memoirs of the New York Botanical Garden 70: 1-182.

Steinmann, V.W. \& Porter, J.M. 2002. Phylogenetic relationships in Euphorbieae (Euphorbiaceae) based on ITS and ndhF sequence data. Annals of the Missouri Botanical Garden 89(4): 453-490.

Tokuoka, T. \& Tobe, H. 1998. Ovules and seeds in Crotonoideae (Euphorbiaceae): structure and systematic implications. Botanische Jahrbücher für Systematik 120(2): 165-186.

Tokuoka, T. \& Tobe, H. 2002. Ovules and seeds in Euphorbioideae (Euphorbiaceae): structure and systematic implications. Journal of Plant Research 115: 361-374.

Tokuoka, T. \& Tobe, H. 2003. Ovules and seeds in Acalyphoideae (Euphorbiaceae): structure and systematic implications. Journal of Plant Research 116: 355-380.

Toledo, A.P. 1963. Anatomia e desenvolvimento ontogenético da flor de mandioca. Bragantia 22(37): 465-476.

Webster, G.L. 1975. Conspectus of a new classification of the Euphorbiaceae. Taxon 24: 593-601.

Webster, G.L. 1994. Synopsis of the genera e suprageneric taxa of Euphorbiaceae. Annals of the Missouri Botanical Garden 81: 33-144. 